\begin{tabular}{lr}
\hline Jurnal Abdimas llmiah & JURNAL ABDIMAS ILMIAH CITRA BAKTI \\
Citra Bakti & Volume 1, Nomor 2, November 2020 \\
(JAICB) & ISSN 2721-9178 \\
\hline
\end{tabular}

\title{
UPAYA MENINGKATKAN MINAT BACA ANAK DESA YAYASAN PROJECT JYOTI BALI (YPJB) MELALUI STORYTELLING DI MASA PANDEMI
}

\author{
Komang Anik Sugiani ${ }^{1)}$, Anak Agung Ngurah Adhijaya ${ }^{2)}$, Made Prima Restami ${ }^{3)}$ \\ 1,2,3)Politeknik Ganesha Guru \\ 1)anikkomang4@gmail.com, ${ }^{2)}$ adhijaya.anakagungngurah4@gmail.com, \\ 3)primarestami@gmail.com
}

\section{Histori artikel}

Received:

31 Oktober 2020

Accepted:

10 November 2020

Published:

30 November 2020

\begin{abstract}
Abstrak
Penelitian ini bertujuan untuk (1) Melekatkan penerapan metode membaca pada minat baca siswa mendongeng di Desa saat era pandemi, (2) melekatkan kebahagiaan, kegembiraan dan kenyamanan dalam menumbuhkan pembaca dan pendengar saat membaca buku dan mendongeng. Jenis penelitian yang digunakan adalah penelitian kualitatif dengan desain penelitian deskriptif kualitatif. Penelitian ini menggunakan wawancara, observasi dan dokumentasi. Objek penelitian adalah siswa Sekolah Dasar Yayasan Project Jyoti Bali. Hasil penelitian menunjukkan bahwa: (1) Tujuan storytelling agar siswa lebih mudah mendapatkan informasi dari narasumber cara membaca buku hasil storytelling dengan baik. (2) Faktor pendukung penerapan sudut baca antara lain: peran orang tua yang tidak memberikan kebiasaan membaca, siswa kurang lancar membaca, buku rusak. (3) Keuntungannya adalah anak mendapatkan pengalaman cerita yang menarik. (4) Anak akan mengenal buku dan mulai gemar membaca buku, sehingga siswa sangat tertarik dan mengakui bahwa menumbuhkan mendongeng dapat membantu minat baca.
\end{abstract}

Kata-kata Kunci : minat baca, storytelling 
Abstrak. This study aims to (1) attach the application of the reading method to students' reading interest in storytelling in the village during the pandemic era, (2) attach happiness, joy and comfort in fostering readers and listeners when reading books and storytelling. This type of research is qualitative research with a qualitative descriptive research design. This study uses interviews, observation and documentation. The research object was the students of the Bali Jyoti Project Foundation Elementary School. The results showed that: (1) The purpose of storytelling is to make it easier for students to get information from the source on how to read the storytelling book well. (2) The supporting factors for the application of a reading angle include: the role of parents who do not give reading habits, students are less fluent in reading, damaged books. (3) The advantage is that children get an interesting story experience. (4) Children will get to know books and begin to like reading books, so that students are very interested and admit that fostering storytelling can help reading interest.

Kata-kata Kunci : reading interest, storytelling

\section{PENDAHULUAN}

Pandemi Covid-19 telah berlangsung sejak awal tahun 2020. Pemerintah telah melakukan beragam upaya dalam mencegah penyebaran virus ini. Beberapa upaya yang telah dilakukan pemerintah antara lain Kebijakan Pembatasan Sosial Berskala Besar (PSBB) dan Adaptasi Kebiasaan Baru (AKB). Kebijakan tersebut mendorong masyarakat untuk menyesuaikan perilaku sesuai dengan protokol kesehatan yang ditetapkan oleh pemerintah. Selain itu, pandemi Covid-19 telah merubah tatanan kehidupan masarakat, dimana aspek kehidupan masyarakat berubah secara cepat. Pandemi covid 19 yang terjadi saat ini menimbulkan berbagai efek dalam kehidupan. Munculnya kebijakan social distancing, lockdown, work from home, school from home membuat kita dilanda kejenuhan dan bahkan mengalami stres. Apalagi yang sudah terbiasa beraktivitas di luar rumah, kegiatan yang menuntut interaksi dan lainnya, pasti sangat merasakan kejenuhan luar biasa. Untuk mengatasi stres berat dan kejenuhan itu, tak ada masalah juga kalau kita baca buku. Membaca buku adalah cara mudah untuk mengatasi stres ketika isolasi diri di rumah. Membaca buku dapat dipraktikkan semua golongan, dari anak-anak hingga orang dewasa. Membaca buku tidak hanya menghilangkan kejenuhan, akan tetapi mempunyai manfaat lain yang sangat baik.

Kegiatan membaca merupakan kegiatan yang sangat bermanfaat bagi semua orang. Dengan membaca banyak diperoleh pelajaran tentang kehidupan. Keberhasilan kegiatan membaca itu merupakan harapan bagi guru maupun orang tua. TIM Dosen Politeknik Ganesha Guru dalam kegiatan Pengabdian Kepada Masyarakat (PKM) yang diadakan di Yayasan Project Jyoti Bali (YPJB), Kecamatan Kubutambahan, Kabupaten Buleleng, Provinsi Bali. TIM Dosen membuat kegiatan dengan tema " Upaya Meningkatkan Minat Baca Anak Melalui Storytelling di Masa Pandemi." Kegiatan ini bertujuan untuk menghibur anakanak dan menumbuhkan minat baca anak dimasa pandemi. Pembinaan kegiatan membaca ini diharapkan akan tercapai apabila ada minat dari dalam diri anak, oleh karena itu diharapkan guru dan orang tua mampu membangkitkan minat anak dalam membaca. Guru 
bahasa diharapkan dapat membantu siswa mengatasi kesulitan membaca dengan mengajarkan teknik membaca yang baik serta memanfaatkan fasilitas yang ada agar budaya baca dapat terwujud. Orang tua harus dapat memberikan dukungan dan memfasilitasi anak untuk membangkitkan minat baca anak.

Membaca merupakan hal penting yang menjadi dasar dalam proses belajar. Kundharu, dkk $(2014,98)$ menjelaskan bahwa, kegiatan membaca perlu dimiliki oleh setiap orang, terlebih lagi oleh pelajar, guru dan peserta didik yang selalu berhubungan dengan buku. Kegiatan membaca perlu ditingkatkan sejak usia dini agar siswa atau peserta didik dapat terbiasa dengan aktifitas membaca. Sesuai dengan pernyataan dari Kundharu, membaca harus dimiliki oleh setiap peserta didik dalam mencari informasi yang diperlukan melalui buku bacaan, selain itu, Naidoo, (2014) menyatakan peserta didik harus mengembangkan berfikir kritis, memanfaatkan waktu membaca untuk mengembangkan kemampuan membaca yang lebih baik. Menurut Rahim, (2007) Mengatakan bahwa "Membaca adalah kegiatan memahami bahasa tulis yang disampaikan oleh penulis". Sedangkan menurut Tampubolon (1990) membaca merupakan suatu proses untuk memahami makna suatu tulisan. Membaca merupakan suatu proses yang dilakukan serta dipergunakan oleh pembaca untuk memperoleh pesan yang hendak disampaikan oleh peneliti melalui media kata-kata atau bahasa tulis (Arimukti, 2001).

Membaca adalah suatu proses yang dilakukan serta dipergunakan oleh pembaca untuk memperoleh pesan, yang hendak disampaikan oleh penulis melalui media katakata/bahasa tulis. Suatu proses yang menuntut agar kelompok kata yang merupakan suatu kesatuan akan terlihat dalam suatu pandangan sekilas, dan agar makna kata-kata secara individual akan dapat diketahui. Kalau hal ini tidak terpenuhi, maka pesan yang tersurat dan yang tersirat tidak akan tertangkap atau dipahami, dan proses membaca itu tidak terlaksana dengan baik (Tarigan, 1985). Membaca merupakan seluruh aktivitas yang dilakukan pembaca untuk memperoleh informasi yang terkandung dalam sebuah bahan bacaan. Produk membaca merupakan hasil dari proses membaca yakni pemahaman atas isi bacaan. Menurut Nurhadi (2004) tujuan membaca memberikan bekal pengetahuan dan kemampuan siswa untuk menguasai teknik-teknik membaca dan menangkap isi bacaan dengan baik dan benar. Dengan adanya beberapa definisi tersebut dapat disimpulkan tujuan membaca adalah sebagai modal bagi seseorang untuk mempelajari buku dan mencari informasi secara tertulis.

Mengembangkan kemampuan membaca anak harus didukung oleh beberapa pihak yaitu pihak sekolah, desa dan orang tua. Beberapa fasilitas yang perlu difasilitasi salah satunya adalah dengan cara membuat membaca itu hal yang menyenangkan. Dalam hal pengembangan bahasa anak, beberapa pihak di atas dapat menggunakan berbagai macam metode dalam penyampaian pesan pembelajaran, yang dapat merangsang dan menambah 
kosa kata anak serta dapat menumbuhkan minat membaca pada anak. Salah satu metode yang dapat digunakan adalah metode bercerita atau storytelling.

Storytelling adalah kemampuan untuk mendongeng (storytelling) adalah keharusan untuk dimiliki. Mereka harus membuat copywriting atau promosi yang alami yang di bingkai dalam cerita menarik. Dengan memberikan sentuhan storytelling maka narasi yang disampaikan akan menghidupkan kata dan pesan yang disampaikan dalam copywriting mudah dimengerti pembaca. Storytelling merupakan sebuah seni bercerita yang dapat digunakan sebagai sarana untuk menambahkan nilai-nilai pada anak yang dilakukan tanpa perlu mengguruiuk anak. Storytelling merupakan suatu proses kreatif anak-anak dalam perkembangannya, sentiasa mengaktifkan aspek intelektual dan aspek kepekaan, kehalusan budi, emosi, seni, daya berfantasi, dan imajinasi anak yang tidak hanya mengutamakan kemampuan otak kiri tetapi juga otak kanan. Berbicara mengenai storytelling, secara umum semua anak-anak senang mendengarkan storytelling, baik anak balita, usia sekolah dasar, maupun yang telah beranjak remaja bahkan orang dewasa.

Kegiatan storytelling, proses bercerita menjadi sangat penting karena dari proses inilah nilai atau pesan dari cerita tersebut dapat sampai pada anak. Pada saat proses storytelling berlangsung terjadi sebuah penyerapan pengetahuan yang disampaikan pencerita kepada pendengar. Proses inilah yang menjadi pengalaman seorang anak dan menjadi tugas guru dan orang tua untuk menampilkan kesan menyenangkan pada saat bercerita. Saat ini berbagai fasilitas pendukung untuk mendongeng mudah didapatkan seperti buku-buku cerita, boneka-boneka, ataupun wayang-wayang kertas. Selain itu juga, sarana pendukung lainnya seperti ruang bermain,VCD, dan DVD, atau film-film yang diangkat dari dongeng-dongeng sebenar.

Storytelling dengan media buku dapat digunakan pencerita untuk memberikan pengalaman yang menyenangkan terhadap anak. Banyak yang tidak menyadari bahwa cara mengajar kepada anak dapat menimbulkan kesan tidak menyenangkan pada saat mula mengenal buku. Pengalaman yang diperoleh anak saat mulai belajar membaca, akan melekat pada ingatannya. Kebanyakan anak merasa dipaksa saat ia belajar membaca. Namun dengan storytelling pengalaman berbeda akan dirasakan oleh anak. Melalui story telling, seorang anak akan belajar membaca tanpa perlu merasa dipaksa untuk melakukannya.

Terdapat berbagai konsep storytelling yang dapat digunakan untuk menarik minat anak untuk membaca. Konsep storytelling dan bermain, storytelling sambil bermain musik, mengadakan festival story telling dengan konsep pementasan teater dari anak untuk anak. Dengan adanya konsep storytelling ini, story teller atau pencerita dapat menampilkan cerita secara menarik dan kreatif sehingga pendengar tidak merasa bosan. Cara bercerita merupakan unsur yang membuat cerita itu menarik dan disukai kanak-kanak. 
Menyajikan storytelling yang menarik bagi anak-anak bukanlah suatu hal mudah untuk dilakukan. Terlebih lagi bagi anak-anak yang hanya berkonsentrasi mendengarkan cerita hanya dalam waktu singkat, jika mendongeng terlalu lama akan membuat anak merasa cepat bosan. Dengan adanya kegiatan storytelling ini tentu dapat meningkatkan minat membaca di kalangan anak. Jadi, dengan adanya kegiatan storytelling yang diadakan oleh TIM dosen Politeknik Ganesha Guru ini apakah akan berpengaruh untuk meningkatkan minat membaca anak usia dini, hal inilah yang peneliti ingin teliti.

Latar belakang peneliti mengangkat tema ini adalah karena storytelling berfungsi untuk memperkenalkan anak-anak agar lebih menyukai suasana dalam merangsang minat baca dan merasa terhibur dengan adanya kegiatan storytelling di desa mereka. Storytelling juga merupakan salah satu cara yang efektif untuk mengembangkan aspek- aspek kognitif (pengetahuan), afektif (perasaan), sosial dan aspek konatif (penghayatan) anak-anak. Berdasarkan latar belakang di atas maka peneliti memilih judul: "Upaya Meningkatkan Minat Baca Anak Desa Yayasan Project Jyoti Bali (YPJB) melalui Storytelling di Masa Pandemi."

\section{METODE PELAKSANAAN}

Jenis penelitian yang digunakan oleh peneliti adalah penelitian kualitatif dengan desain penelitian deskriptif. Data yang digunakan dalam penelitian ini meliputi data tentang: membaca melalui storytelling, faktor pendukung dari implementasi storytelling, hambatan apa saja yang dialami, upaya apa yang dilakukan desa dalam mengoptimalkan storytelling dalam menumbuhkan minat baca anak. Objek empat penelitian yang di gunakan adalah kepala desa, Ketua Yayasan Project Jyoti Bali, orang tua, dan anak Desa. Dalam penelitian ini teknik pengumpulan data yang digunakan adalah teknik triangulasi sumber dan teknik. Teknik analisis yang digunakan dalam penelitian ini adalah penyajian data dan penarikan kesimpulan.

\section{HASIL DAN PEMBAHASAN}

Penelitian ini dilakukan untuk optimalisasi minat baca anak Desa Yayasan Project Jyoti Bali (YPJB) Kecamatan Kubutambahan, Kabupaten Buleleng, Provinsi Bali dengan menggunakan storytelling. Berdasarkan informasi yang didapat dari Kepala Desa dan perangkat desa, minat baca anak di Desa Medalsari sangat kurang apalagi dimasa pandemic sekarang ini. TIM dosen Politkenik Ganesha Guru mempunyai gagasan untuk menumbuhkan minat baca anak melalui storyteling. Adapun tahap-tahap pelaksanaan yang kami berikan ketika kegiatan antara lain: 


\section{Tahap Pelaksanaan Siklus I}

1) Pemateri membagi anak menjadi kelompok kecil.

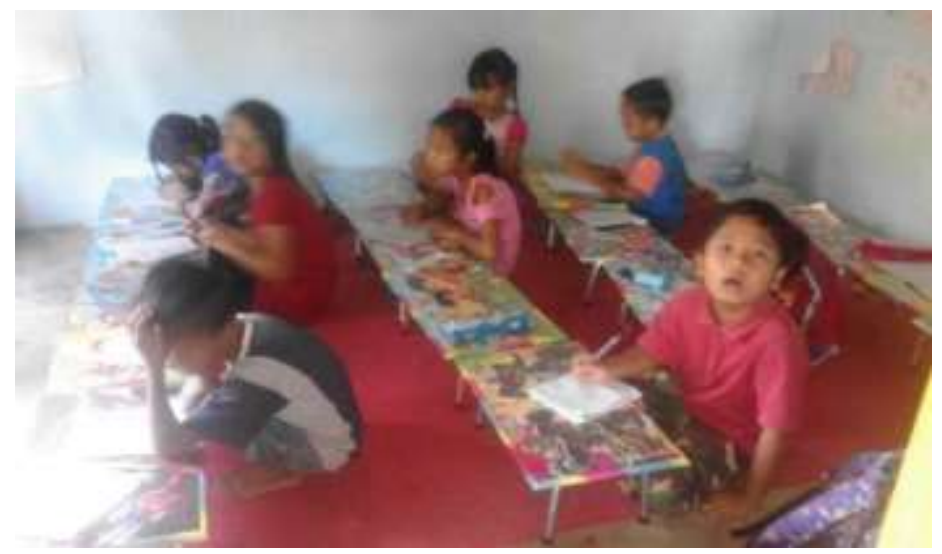

Gambar 1. Pembagian Kelompok

2) Pemateri menunjukkan buku storytelling kepada anak, dengan tema bacaan yang beragam.

3) Pemateri mengenalkan buku storytelling yang akan digunakan, berupa buku bergambar dengan tulisan besar yang berisi cerita menarik.

4) Pemateri menjelaskan tentang cara membaca buku storytelling.

5) Setelah anak mampu membaca buku storytelling dengan lancar dan tanpa kesalahan maka pemateri memberikan reward yang berupa alat tulis.

6) Penutupan kegiatan dengan doa. Pada akhir kegiatan pemateri membuat kesimpulan yaitu jika anak meningkat minat bacanya, dalam arti dapat menyelesaikan membaca dengan baik maka ada perubahan yang lebih baik lagi dan perkembangan yang meningkat dalam minat baca anak.

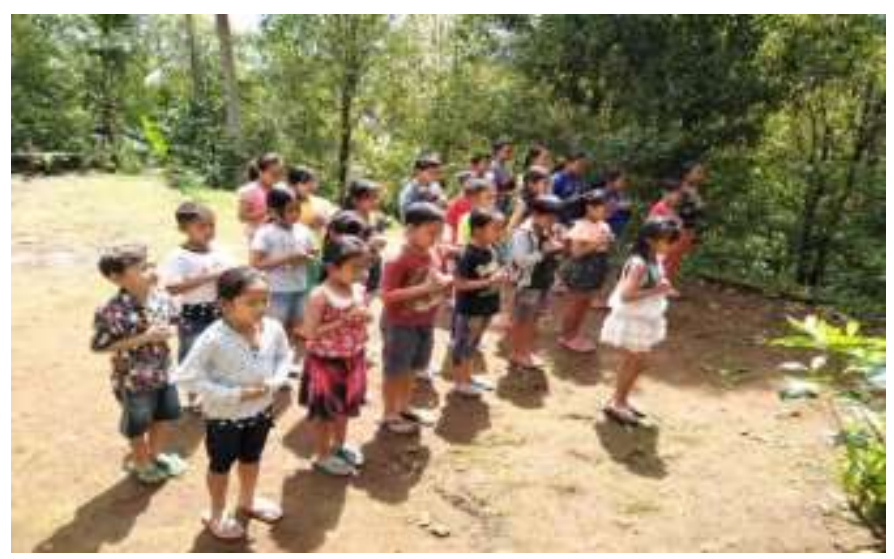

Gambar 2. Doa 


\section{Tahap Observasi}

Kegiatan pengamatan atau observasi dilakukan bersama-sama dengan pelaksanaan tindakan berlangsung dibantu oleh orang tua dan pengurus Yayasan Project Jyoti Bali (YPJB). Adapun maksud diadakannya observasi adalah untuk mengetahui perubahan minat baca anak. Kegiatan yang dilakukan oleh orang tua dan pengurus Yayasan adalah mengamati kegiatan peneliti, apakah peneliti benar-benar telah melakukan upaya untuk memperbaiki proses pembelajaran sehingga dapat membantu meningkatkan minat baca anak.

\section{Refleksi Siklus I}

Refleksi dimaksudkan sebagai upaya mengkaji apa yang telah dan belum terjadi, apa yang dihasilkan, kenapa hal itu terjadi, dan apa yang perlu dilakukan selanjutnya. Dari hasil refleksi yang telah dilakukan pada siklus I ini diketahui bahwa telah ada peningkatan minat baca anak. Anak sudah ada ketertarikan yang lebih baik terhadap materi storytelling yang dibacakan, namun masih terdapat beberapa kelemahan yang memerlukan perbaikan. Adapun perbaikan yang dilakukan adalah:

1. Lebih mengkondusifkan suasan dalam proses pembelajaran, sehingga anak tidak ribut.

2. Mengoptimalkan peran peneliti dalam pembelajaran agar sesuai dengan yang diharapkan pada pembelajaran.

3. Lebih aktif dalam pembelajaran dalam upaya peningkatan minat baca anak melalui kegiatan storytelling.

4. Memberikan penghargaan yang berupa alat tulis.

5. Peran orang tua harus optimal.

Oleh karena itu diperlukan siklus berikutnya untuk memperbaiki dan meminimalisir kelemahan-kelemahan yang terjadi pada siklus I.

\section{Tahap Pelaksanaan Siklus II}

Adapun langkah-langkah yang telah dilaksanakan adalah sebagai berikut:

1) Pemateri membagi anak menjadi kelompok-kelompok kecil, namun anggota kelompok diubah atau berbeda dari pertemuan sebelumnya.

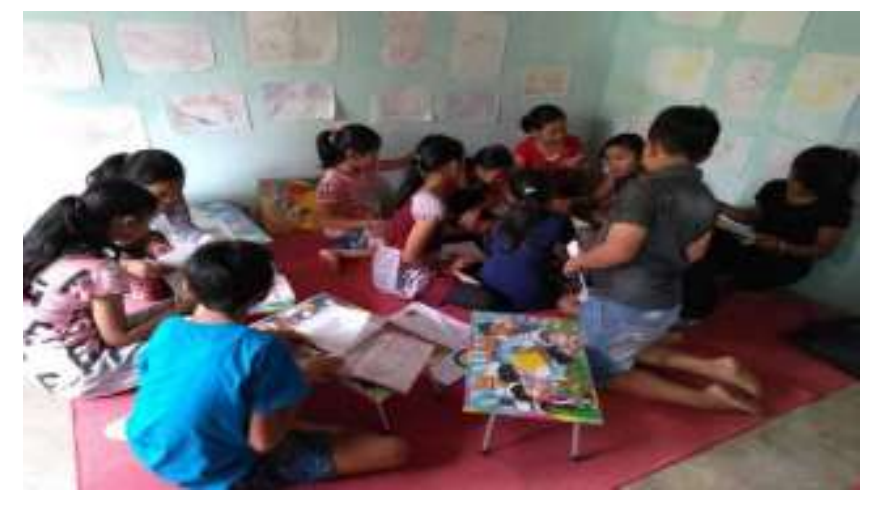

Gambar 3. Pembagian Kelompok 
2) Pemateri menunjukan buku storytelling kepada anak, dengan tema yang beragam.

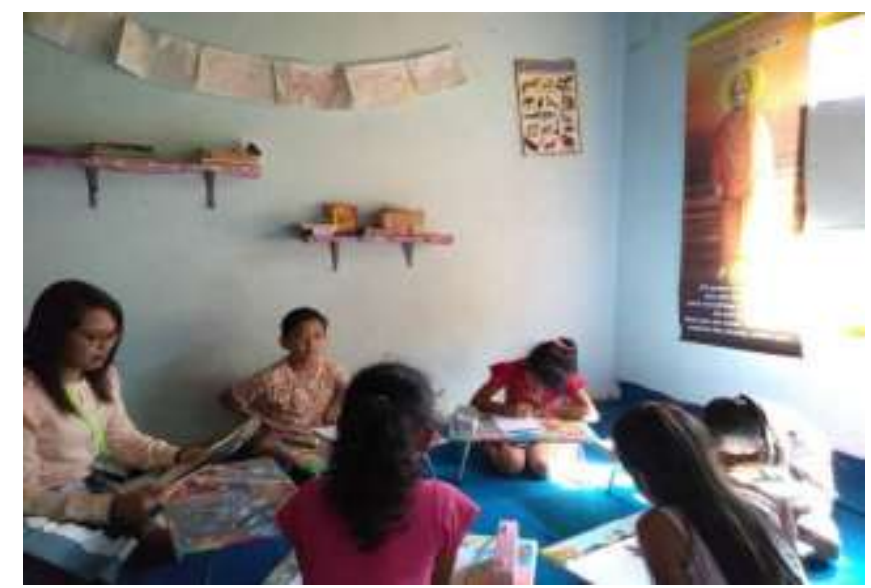

Gambar 4. Peneliti memberikan Buku Storytelling

3) Pemateri mengenalkan buku storytelling yang akan digunakan, berupa buku bergambar dengan tulisan besar yang berisi cerita menarik.

4) Pemateri menjelaskan tentang cara membaca buku storytelling.

5) Setelah anak mampu membaca buku storytelling dengan lancar dan tanpa kesalahan maka pemateri memberikan reward yang berupa alat tulis.

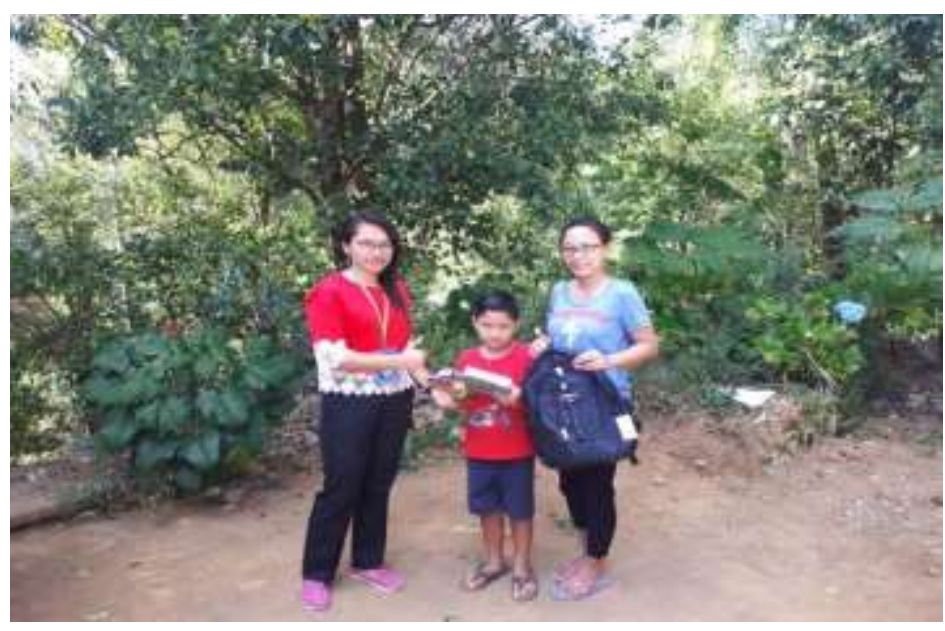

Gambar 5. Peneliti Memberikan Reward Perlengkapan Sekolah

6) Selanjutnya peneliti menutup kegiatan dengan doa. Pada akhir kegiatan pemateri membuat kesimpulan yaitu jika anak meningkat minat bacanya, dalam arti dapat menyelesaikan membaca dengan baik maka perubahan dan perkembangan minat baca anak. 


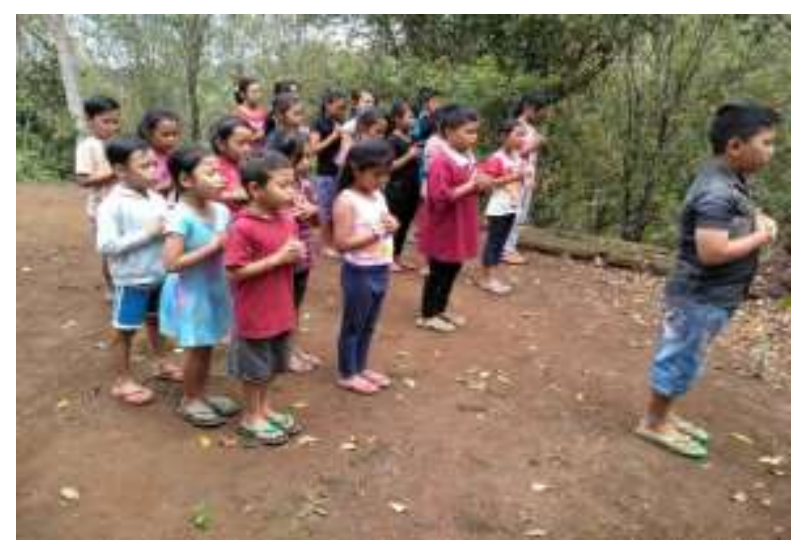

Gambar 6. Doa

\section{Tahap Observasi}

Kegiatan pengamatan atau observasi dilakukan bersama-sama dengan pelaksanaan tindakan berlangsung dibantu oleh orang tua dan pengurus yayasan. Adapun maksud diadakannya observasi adalah untuk mengetahui perubahan minat baca anak. Kegiatan yang dilakukan oleh orang tua dan pengurus yayasan adalah mengamati kegiatan peneliti, apakah peneliti benar-benar telah melakukan upaya untuk memperbaiki proses pembelajaran sehingga dapat membantu meningkatkan minat baca anak.

\section{Refleksi Siklus II}

Refleksi dimaksudkan sebagai upaya mengkaji apa yang telah dan belum terjadi, apa yang dihasilkan, kenapa hal itu terjadi, dan apa yang perlu dilakukan selanjutnya. Hasil refleksi ini digunakan untuk merencanakan dan mengadakan perbaikan pada pelaksanaan tindakan selanjutnya. Jika terdapat masalah dalam proses refleksi, maka sudah seharunya pemateri sebagai peneliti melakukan pengkajian ulang pada siklus berikutnya. Dari refleksi ini diketahui keberhasilan maupun kegagalan atas pelaksanaan tindakan siklus II, yang ditunjukan dengan prosentase nilai anak dalam minat baca.

\section{Pembahasan}

Antusias membaca anak Desa di Yayasan Project Jyoti Bali (YPJB) sangatlah tinggi, namun masih ada beberapa kendala yang membuat minat baca mereka masih kurang. Tanda-tanda kurangnya minat baca ini antara lain anak tidak mau memperhatikan saat pemateri memberi contoh cara membaca buku storytelling, anak tidak konsentrasi dalam membaca, atau anak sibuk main sendiri. Oleh karena itu, pada kesempatan ini peneliti mengadakan penelitian yang mengangkat tema "Upaya Meningkatkan Minat Baca Anak Desa Yayasan Project Jyoti Bali (YPJB) melalui Storytelling di Masa Pandemi." Upaya peningkatan yang dilakukan adalah dengan menggunakan metode storytelling. 
Dari hasil penelitian pada siklus I menunjukan bahwa diketahui bahwa telah ada peningkatan minat baca anak. Anak sudah mempunyai ketertarikan yang lebih baik terhadap materi storytelling yang dibacakan. Namun pencapaian ini masih belum bisa dikatakan maksimal dan masih terdapat beberapa kelemahan. Peneliti melakukan beberapa peraikan yang dirasa sangat perlu dilakukan agar pada tindakan silklus II nanti dapat berjalan lebih baik dan maksimal. Adapun perbaikan tersebut adalah sebagai berikut: (1) mengoptimalkan peran peneliti dalam pembelajaran agar sesuai dengan yang diharapkan pada pembelajaran, (2) lebih aktif dalam pembelajaran dalam upaya peningkatan minat baca anak melalui kegiatan storytelling, (3) lebih aktif memberi reward pada hasil pencapaian anak, (4) peran pemateri harus optimal.

Dengan adanya revisi pelaksanaan tindakan pada siklus II maka hasil yang dicapai sudah cukup memuaskan. Pada akhir siklus II diketahui bahwa pencapaian hasil belajar beberapa kelompok menunjukkan bahwa lebih dari 50 persen anak memiliki nilai baik sekali, sisanya termasuk pada kategori baik. Ini membuktikan bahwa kegiatan storytelling yang dilakukan sudah berjalan dengan sangat baik, karena mampu meningkatkan minat baca anak tanpa membutuhkan waktu yang terlalu lama.

\section{KESIMPULAN}

Proses pembelajaran pada saat penelitian berjalan dengan baik dan sesuai dengan rencana yang telah ditetapkan. Peningkatan minat baca melalui pembacaan cerita (storytelling) berjalan dengan baik dan anak cukup antusias mendengarkannya. Dengan demikian storytelling dianggap efektif sebagai metode pembelajaran dalam meningkatkan minat baca anak. Berdasarkan hasil observasi yang telah dilakukan, Pada akhir siklus II diketahui bahwa pencapaian hasil belajar beberapa kelompok menunjukkan bahwa lebih dari $50 \%$ anak memiliki nilai baik sekali, sisanya termasuk pada kategori baik. Ini membuktikan bahwa kegiatan storytelling yang dilakukan sudah berjalan dengan sangat baik.

\section{DAFTAR PUSTAKA}

Arimukti. (2001). Hubungan antara kemampuan membaca pemahaman siswa kelas II smu negeri grobogan dengan penguasaan kosakata dan frekuensi membaca. Tersedia pada: http://www.digib.petra.ac.id diakses tanggal 27 Agustus 2020.

Boltman, A. (2001). Children story telling technology differences in ellaboration and recall. Pennsylvania: Pennsylvania State University.

Kundharu, S., \& Slamet, S. Y. (2014). Pembelajaran keterampilan berbahasa Indonesia; Teori dan aplikasi. Edisi 2. Yogyakarta: Graha Ilmu.

Kusumastuti, D. N. (2010). Pengaruh kegiatan storytelling terhadap pertumbuhan minat baca siswa di TK Bangun 1 Getas Kecamatan Pabelan Kabupaten Semarang. Semarang: Universitas Diponegoro. 
Naidoo, U., Reddy, K., \& Dorasamy, N. (2014). Reading literacy in primary schools in South Africa: Educator perspectives on factors affecting reading literacy and strategies for improvement. International Journal of Educational Sciences, 7(1), 155-167.

Nurhadi. (2004). Bagaimana meningkatkan kemampuan membaca?. Bandung: Sinar Baru.

Ortlieb, E. T. (2010). Beyond just books: sparking children's interest in reading. International Journal of Education, 2(2), 2-4.

Rahim, Farida. (2007). Pengajaran membaca di Sekolah Dasar. Jakarta: Bumi Aksara.

Serrat, O. (2008). Storytelling. Manila: The Asian Development Bank (ADB).

Tampubolon. (1990). Kemampuan membaca teknik membaca efektif dan efisien. Bandung: Angkasa.

Tarigan, Henry Guntur. (1985). Membaca sebagai suatu keterampilan berbahasa. Bandung: Angkas 